DOI https://doi.org/10.36059/978-966-397-142-1/105-122

\title{
GENERAL DESCRIPTION OF INFORMATION RELATIONSHIP IN ADMINISTRATIVE LAW
}

\section{Korniyenko M. V.}

\section{INTRODUCTION}

The study of information relations, which are governed by the rules of administrative law, has always been a daunting task. It was complicated even more when the actual change in the socio-political system began to take place in the state. Destructive social foundations that existed for decades, are subjected to revision of immutable in the recent past ideological postulates, formed new management schemes of relations, through which realized the generalized information needs of society. All this requires a new thorough study of information relations subject to administrative regulation, the need to outline their characteristic properties.

In the legal doctrine at the time two main (and opposite) views on the interpretation of legal relations and actual social relations, which are the subject of legal regulation, were formed. As part of the first approach, legal relations are equated with social relations, almost identical with them. So, V.S. Afanasyev, A.P. Gerasimov, V.I. Hoyman argue that the legal relationship, being at the same time social relations, objectively arise and exist to the law in the form of social interaction of their participants.

The position of scientists of the second group, including A.B. Vengerov, P.M. Rabinovich, O.F. Skakun, V.M. Khropanyuk is not only the opposite, but also more common in comparison with the position of the representatives of the first group of scientists. Its essence can be formulated with such a thesis: public relations in no way equal to the legal relationship. The idea of the adherents of this concept is expressed in the fact that the concept of "legal relationship" and "social relations" are not identical. Public relations is a primary category that is wider than the category of "legal relations", which is considered as one of the types of social relations, however, not all of those that arise in society, but only those that are regulated by law.

We believe that the circle of social relations really turns into legal relations - both at the scientific and theoretical level - in connection with the expansion of the scope of their legal regulation in society. 


\section{The essence and peculiarities of information relations that are subject to administrative-legal regulation}

Modern domestic scientists propose a variety of definitions of administrative-legal relations and their characteristic features: public relations in the sphere of public administration, whose participants are the bearer of rights and freedoms regulated by the norms of administrative $\mathrm{law}^{1}$; as a result of the influence of administrative and legal norms on the behavior of subjects of the sphere of public administration, as a result of which between them there are established legal ties of state power ${ }^{2}$; as a system of rights and obligations of executive bodies, officials and employees, citizens and other entities, as well as the interrelation between them as a result of the exercise of state executive power and responsibility in the field of public administration ${ }^{3}$.

The content of these options, which characterize the features of the relations of administrative law, indicates their unconditional, organic connection. They have a unified conceptual basis, proposed by Yu.M. Kozlov. The basis of significant features of administrative-legal relations are six decisive features. The first concerns the sphere in which the administrative law relations arise (arise). The second determines the obligatory presence as one of the parties of the body, endowed with power and administrative powers. The third one points to the conditions of the mentioned relations. The fourth feature defines the nature of the relationship between the participants in these social relations. The fifth concerns the issues of liability to the state for violating the requirements of administrative law. The sixth determines the procedure for resolving disputes between the participants in administrative-legal relations.

It seems expedient to pay attention to the extent to which information relations arranged by the rules of administrative law coincide with the administrative, which information circulation is regulated or should be regulated by these norms. Thus, G.M. Lynnyk outlines the main features of administrative legal relations in the information sphere: they arise, change, cease only if there is an

1 Доповідь про стан інформатизації та розвиток інформаційного суспільства в Україні за 2013 рік. URL.: http://www.dknii.gov.ua/sites/default/files/stan_ informatyzacii_20132.pdf.

2 Залізняк В. Удосконалення інформаційного законодавства України : методологічні засади. Інформаційне право. 2010. № 2. С. 59-60. С. 59.

${ }^{3}$ Панова I. В. До проблем правотворення в інформаційному праві. Правова інформатика. 2015. № 1 (45). С. 35-40. С. 37. 
appropriate administrative norm; one of the subjects of legal relations is the holder of the power of attorney, namely: state authorities, local selfgovernment bodies, their officials and officers, and other entities exercising executive power, including delegated powers; the existence of mutual subjective rights and legal obligations, provided by the state; clear, personalized relationship; the will of at least one of the subjects of administrative law; limited sphere of existence, namely the sphere of public-legal relations (state and self-government); arise, change and terminate in connection with the receipt, use, distribution and storage of information; the information component of administrative legal relations can play both a decisive role and an auxiliary role; the priority of information rights, freedoms and legitimate interests of man and citizen in the field of public administration.

Agreeing with the thesis that the administrative-legal forms can acquire different types of social relations, first of all, public-managerial relations ${ }^{4}$, information relations in administrative law can be considered as the result of the regulatory influence of the administrative-legal norm on public information relations, as a result of which they turn into informational administrative legal relationship.

Concluding the analysis of the characteristic features of the administrative-legal relations, one can confidently state that the development of information technologies and the constant change in the organizational foundations of the activities of the state administration make updating the domestic administrative law. Therefore, the content of the characteristic features may acquire new features that will reflect the results of further transformation of administrative-legal relations.

The peculiarity of information relations subject to legal regulation is that they are at the crossroads of public and private law and are steadily serving as the subject of scientific work of specialists from the constitutional, administrative, financial, civil and other branches of law. This is contributed by many factors. First of all, this is the significance of information relations for the state and society, as well as the permanent (permanent) reformation of the information social sphere, which directly affects the development of the state. The considerable interest of scholars is due to the availability of information relations in various spheres of public life.

${ }^{4}$ Адміністративне право України: акад. курс : підручник. У 2 т. Т. 1. Загальна частина / за ред. В. Б. Авер'янова. Київ : Юрид. думка, 2004. 584 с. С. 177. 
Lawyers, considering the issues of information relations subject to legal regulation in various branches of law and life spheres, try to outline their specifics and features in a certain subject area. In our opinion, the necessity of properly studying the genesis of the essence and the definition of the concept of "information legal relations" in scientific doctrine is due to the role played by the legal relationship in the process of legal regulation of various social relations. The preliminary analysis of scientific legal sources, which in one way or another reveals this category, allows us to speak about the lack of a clear, understandable and qualitative interpretation. In particular, there is clearly a lack of consensus on the notion of "sphere of public relations", in which the administrative-legal regulation of information relations takes place. There is also a tendency to mix these concepts (in particular, "information relations" and "information legal relations", "administrative-legal regulation of information relations" and "administrative and legal regulation of information legal relations", etc.), resulting in further confusion between constructions.

In general, the allocation of information relations as independent was based on the fact that information relations arise in connection with information processes, have a social content - serve social goals, express and reflect certain social interests that arise between social groups. The main factor that led to the allocation of information legal relationships from the system of legal relations, V.P. Gorbulin and M.M. Bichenok called the emergence of a system of commercial distribution of information and a system of specialized, created to meet the public needs of organizations that form a special branch of the economy, which led to the emergence of a special branch of social relations ${ }^{5}$.

The state of uncertainty in information relations subject to legal regulation is largely due to a different approach to terminology and to the personal view of the subject of research. In our opinion, this issue can be solved by establishing what these information relationships are - "private" or "public-law" When it comes to public relations, it can be argued that they are within the scope of public administration and governed by administrative law, is its subject.

What information relations are subject to administrative regulation? To answer this question, first of all, let's decide what features are inherent in public-legal relations. Give them. The notion of "public" (from the

${ }^{5}$ Горбулін В. П., Биченок М. М. Проблеми захисту інформаційного простору України : монографія. Київ : Інтертехнологія, 2009. 136 с. С. 61. 
Latin social, folk) should be understood as "open", "vowel", "social". As V.M. Bevzenko, regarding the publicity of legal relations, we can say that these relations, which arise, spread, or may spread to society as a whole or to a significant part of it, and because of this, have a general significance, universal nature ${ }^{6}$.

Another sign that allows us to conclude that the public nature of information legal relations is the presence in such relations of such an element as a legal obligation, which, according to A.I. Elistratov, is in any circumstances available as part of public legal relations. It should also be added that the legal obligation is prescribed by law in order to ensure the achievement of a specific social and public result:

- satisfaction of legal interests or the creation of certain benefits (privileges) for a significant number of participants in public relations. These interests are heterogeneous and often contradict each other (interests of the state - interests of the territorial community, interests of the territorial community - interests of the concrete person, etc.). Legal interest can be defined as an endeavor to provide benefits that are of general social significance, that is, the benefits that are important not to one person but to a significant number of people;

- assistance in realization and protection of subjective rights, freedoms, interests by physical and legal persons. For example, according to the norms of the Law of Ukraine "On access to public information", information managers are obliged: to determine the special places for the requesters to work with documents or their copies; have special structural subdivisions or appoint responsible persons to provide applicants with access to information and disclosure of information; provide and disclose accurate, accurate and complete information, as well as, if necessary, verify the accuracy and objectivity of the information provided and update the disclosed information;

- performing public tasks and functions entrusted to a particular body, such as, for example, the protection of subjective rights, freedoms, interests, etc.

Part of modern scholars argues that for public-legal relations is characterized by an exclusively imperative method of legal regulation, and therefore these relations are formed on the basis of powersubordination. Quite often, the imperative method is manifested in the

${ }^{6}$ Бевзенко В. М. Сутність та поняття адміністративно-правового регулювання. Вісник господарського судочинства. 2006. № 3. С. 162-167. С. 163. 
prohibition of certain actions. With this understanding of the method of legal regulation of public-legal relations, it is difficult to agree, since today these ties, unlike the period of Soviet statehood, arise, develop and cease also on a voluntary basis.

As repeatedly noted in the literature, the construction of "pure" branches of law is impossible. The subject of legal regulation, on the basis of which it was proposed to do, could not stand checking the realities of law-making, law enforcement and scientific activities. R.S. Melnyk, investigating the new subregistry of administrative law, says that quite often it is not primarily about the creation of new normative formations, but about the search for the most successful title (form) for existing ones.

Given the analysis carried out it is possible to conclude that the administrative law regulates public-legal information relations, which inherent in all the properties of administrative legal relations and which have their own distinctive features, separating them from civil law relations. Information relations in administrative law are regulated by the norms of administrative law public-law information relations, in which their parties (subjects) are interconnected and interact with the implementation of subjective rights and obligations established and guaranteed by the relevant administrative-legal rules.

On the basis of the above, we see it possible to distinguish the following features of information relations that are subject to administrative regulation:

- public-law information relations are always social relations regulated by the norms of public law, the main idea of which is to ensure harmony and agreement in society, balance of interests of the individual, collectives, communities and society as a whole, the stability of the state and its institutions, the stability of the foundations of economic and social development;

- public-law information relations arise and spread in a society or a significant part of it;

- in the public-legal information relations a legal obligation is carried out, which is carried out with the purpose of realization of general public needs: 1) satisfaction of legal interests in the information sphere; 2) assistance in the implementation and protection of subjective information rights, freedoms, interests; 3) execution of public (public, public) tasks and functions entrusted to a specific body; 4) implementation of auxiliary functions of a public nature aimed at ensuring the normal fulfillment by the subjects of the authorities of the main tasks; 
- a participant in public-legal information relations, except for natural persons or legal entities, is necessarily a subject of authority, which in such legal relationships performs the legal duty entrusted to him/her;

- in the public-legal information relations of the continuous submission of the will of the subject of public authority does not exist, however, in the case of the emergence of legal relations of a public nature with this subject, the interested person (physical or legal) bears the obligation to adhere to the rules of law of certain rules of behavior.

\section{Administrative and legal principles of information relations}

Information relations regulated by administrative law are characterized by considerable dynamism and instability of legal regulation. By providing diverse social processes, individual groups of these relationships over time lose their relevance and undergo radical changes, such as administrative services, e-governance and e-democracy. Thus, constantly changing and adjusted, the system of public needs in the information sphere caused changes and adjustments of administrative law. It generates new or updated social relations in the power and management sphere - information relations, which have specific features and properties.

Creating the legal framework for information relations can be divided into several stages. The first (1991-1994) formed the foundations in the field of informatization. The second stage (1994-1998) was characterized by a change in the priorities from informatization to the development of information policy. The third stage, which continues to this day, is the stage of formation of the policy in the field of construction of an information society. The main tasks, ways of solving problems, tasks and functions of the authorities, mechanisms of interaction between them and society, citizens and business, as well as conceptual principles of the state policy in the field of informatization, development of the information society and e-governance are defined in a number of legislative acts such as : The Constitution of Ukraine, the Laws of Ukraine "On Information", "On the National Program of Informatization", "On Access to Public Information", "On Protection of Personal Data", "On Administrative Services", "protection of information in information and telecommunication systems", "On electronic document and electronic document circulation", "On electronic digital signature"; a series of international legal acts that led to the adoption of laws: the Declaration of Principles "Building the Information Society- A Global Task in the New 
Millennium" of 12.12.2003, Directive 95/46 / EC of the European Parliament and of the Council "On the Protection of Individuals with Personal Processing" data and the free movement of such data "of 24 October 1995, Directive 97/66 / EC of the European Parliament and of the Council of ..." On the processing of personal data and the protection of the right to privacy in the private sector in the telecommunications sector", the Convention I on the protection of individuals with regard to the automated processing of personal data of January 28, 1981, etc.

We emphasize that there is still a whole range of unresolved issues of regulatory, organizational, technical and resource support for the development of the information society. Unfortunately, the sphere of informatization and information society develops rather slowly, not systematically, which leads to imbalance of the state of the domestic information society and the loss of Ukraine's position in world rankings.

The main reason for this state of affairs is the uncertainty of legal principles and organizational and technical decisions regarding the implementation of e-governance, the lack of a unified approach to the use of tools and mechanisms for organizing and coordinating the activities of state bodies in the field of information.

An important step in the regulation of relations for ensuring the preservation and protection of information in the field of migration was the Concept for the establishment of a unified information and analytical system for managing migration processes approved by the decree of the Cabinet of Ministers of Ukraine dated November 7, 2012 No. 870-p, which defines the ways and stages of creating a single informationanalytical system of management of migration processes, the application of which is aimed at automating the activities of the State Migration Service and taking into account the best experience of the European Union system of state management of migration processes in accordance with the standards of the European Union.

An important stage in the regulation of relations in the field of personal data protection was the ratification by Ukraine in 2010 of the Convention on the Protection of Personal Data with regard to Automatic Processing of Personal Data and the Additional Protocol to the Convention on the Protection of Personal Data with regard to Automatic Processing of Personal Data in respect of Supervisory Bodies and crossborder data flows". The purpose of the Convention is to ensure, on the territory of the country, for every person, regardless of his/her nationality or place of residence, the observance of his/her rights and fundamental 
freedoms, in particular his/her right to privacy, in connection with the automated processing of personal data relating to it.

In order to implement the provisions of the said convention at one time, the Law of Ukraine "On Protection of Personal Data" was adopted, which detailed the principles of regulating legal relations related to the protection and processing of personal data, and aimed at protecting fundamental human and civil rights and freedoms, in particular, the right to non-interference in privacy, in connection with the processing of personal data. The law provides for terms, in particular, "owner of personal data" and "personal data manager", "agreement of the subject of personal data", "processing of personal data", etc.

At the request of the provisions of the above-mentioned law, the sublegislative legislative framework for regulation of relations in this sphere has also been modernized. Thus, the Order of the Ministry of Justice of Ukraine dated July 22, 2013 No. 1466/5 amended certain orders of the Ministry of Justice of Ukraine to improve the legal regulation in the field of personal data protection, in particular, the Typical procedure for processing personal data in the databases of personal data, approved by the order of the Ministry of Justice Of Ukraine dated December 30, 2011 No. 3659/5, as well as to the order of the Ministry of Justice of Ukraine dated July 8, 2011, No. 1824/5 "On approval of application forms for registration of personal data base and changes to the data of the States register of personal data and the order of their submission".

The State Program for the Promotion of Economic Development for 2013-2014, approved by the Resolution of the Cabinet of Ministers of Ukraine of February 27, 2013 No. 187, included: "Improvement of legislation to stimulate the development of the domestic IT industry, in particular, taxation of software product industry subjects", Which will ensure" the creation of domestic import-replacement software products or increase the volume of exports of not less than 3 billion hryvnias; an increase in the amount of revenues from the payment of a single contribution to the mandatory state social insurance during the first year by UAH 120 million, the next five years - by UAH 4274 million; accelerating the development of the software industry to 40-45 percent per year; an increase in the number of jobs each year by 35-40 percent (more than 20 thousand per year)".

The concept of the creation and functioning of the information system of electronic interaction of state electronic information resources, approved by the Cabinet of Ministers of Ukraine from September 5, 2012, 
No. 634-p, identified as a problem that needs to be solved the fact that the only infrastructure of interagency information interactions of state bodies and business entities with the use of information technology is not created, and the Single Web portal of executive bodies, which should be the basis of the integrated system "E-Government" performs mostly presentation and information functions ${ }^{7}$.

The basic document regulating activity in the field of providing administrative services is the Law of Ukraine "On Administrative Services" (of September 6, 2012 No. 5203-VI), which defines the legal framework for the realization of the rights, freedoms and legal interests of individuals and legal entities in the field of provision administrative services.

In order to enforce the above-mentioned law, state authorities have begun the formation of a legislative framework for the provision of administrative services, in particular, in electronic form. Approximately ten normative acts regulating the maintenance of the Register of Administrative Services, the Unified State Portal for Administrative Services, the activities of the centers for the provision of administrative services, etc., were adopted. The procedure for the provision by the authorities of the Pension Fund of Ukraine of services in electronic form, approved by the Resolution of the Board of the Pension Fund of Ukraine dated September 7, 2012, No. 16-1, determines the mechanism of provision by the territorial authorities of the Pension Fund of Ukraine services in electronic form, based on technologies of remote access and automated transmission and information processing. The following electronic services are provided:

1. Registration of users on a web-portal.

2. Access to the information on the web portal: a) for citizens and insured persons: 1) on the procedure for registration of citizens in the database of the web-portal; 2) the rights, responsibilities and responsibilities of the recipients of pension and other payments made by the Pension Fund of Ukraine; 3) on the procedure for obtaining and using a pension certificate; 4) about the conditions, the procedure for appointment, recalculation and payment of pensions, etc.; 5) samples of applications, complaints, requests for information, other documents

${ }^{7}$ Концепція створення та функціонування інформаційної системи електронної взаємодії державних електронних інформаційних ресурсів. Офіційний вісник України. 2012. № 67. Ст. 2753. 
necessary for the appointment and recalculation of pensions, transfer from one type of pension to another, changes in the way of payment of pensions, payment of burial assistance, etc.; 6) on the rights, duties and responsibilities of insured persons; 7) on the procedure for obtaining and using the certificate of compulsory state social insurance; 8) on the procedure for the reception of citizens in the territorial bodies of the Pension Fund of Ukraine on the principle of "single window".

3. Access for citizens, insured persons and insured persons, including individuals - entrepreneurs and persons who provide themselves with work independently, to information on the state of the information about the insured person, pension payments, processing of the report filed electronically.

4. Interaction of citizens, insured persons and insured persons, including individuals - entrepreneurs and persons who provide themselves with work independently, with territorial bodies of the Pension Fund of Ukraine on the following questions: 1) filling in forms of application, complaints, requests in electronic form; 2) I will consider applications, complaints, requests submitted electronically; 3) filing requests for the paperwork of certificates and other documents received by the applicant during a personal appeal to the territorial bodies of the Pension Fund of Ukraine; 4) preliminary record for admission in its territorial body.

5. Obtaining other necessary reference information.

Thus, we can talk about the substantial modernization of the administrative and legal principles of regulation of information relations, in particular, regarding the formation and implementation of a national policy on the development of the information society, informatization and e-governance, which allows to realize a significant number of tasks of further socio-economic and political development of Ukraine, harmonious joining the world information community.

In accordance with the Concept of State Information Policy, in recent years significant modernization of the legislative framework for the formation and implementation of the national policy on the development of the information society, informatization and e-government, which allows to realize a significant number of tasks of further socio-economic and political development of Ukraine, harmonious entry into the world informational community. 


\section{Genesis of information relations in administrative law}

With the development of information technology, information has become the most expensive resource. To facilitate the search, exchange and processing of information humanity began to use personal computers connected to the Internet. Computerization and Internet have affected almost all aspects of human activity: from contracts to personal relationships, from purchasing goods through online stores to training. Computers have greatly simplified the work of the person, performing the machine work for her. The World Wide Web has reduced the time to search for the necessary information by using the search engines of the services that search for a user-specified query. Global informatization and computerization have led to the rapid development of a software market that provides both search and information protection.

Ukraine has been actively involved in the global process of creating an information society open to the public, in which everyone will have the opportunity to express their opinions freely and be heard. The four documents adopted on the outcome of the World Summit on the Information Society (Geneva Declaration of Principles, the Geneva Action Plan, the Tunis Commitment, the Tunis Agenda for the Information Society) call on the world community to build an information society focused on people's interests, open to all, in which everyone could create, access, use and share information and knowledge.

Each state social system had its own characteristics, its values, which are determined primarily by the material and spiritual needs of man. Each stage of human development is characterized by its special properties, which flow into the general norms of behavior, relationships and values. Some criteria for evaluating this or that phenomenon are formed ${ }^{8}$. Humanity has come to the necessity of forming a new outlook, to the fact that it is necessary to rethink some values, that is, a new outlook is formed.

Consciousness as a system includes various forms of reflection of social relations: political, legal, ethical, philosophical, religious. All forms of social consciousness are interdependent and have a mutually influential influence on one another. In turn, justice constitutes a relatively independent sphere (area) of consciousness: social, group, individual. It reflects the legal validity in the form of knowledge about the right,

${ }^{8}$ Баранов О. А., Жиляєв І. Б., Семенченко А. І. Українське інформаційне право на початку XXI століття. Інформатизація та відкритість влади як засоби демократизації суспільства. Київ : Либідь, 2003. С. 88-100, с. 97. 
comprehension of what is the right, what it was and what it should be (relation to future law), as well as in the form of legal guidance of behavior as a reaction to the assessment of the current law, the work of law enforcement agencies.

Thus, legal consciousness is defined as a system of ideas, ideas, emotions and feelings that express the attitude of the individual, group, society to the current, past and desired law, as well as to the activity related to the right.

In the structure of the person's legal conscience, each of the functions corresponds to the following blocks: 1) legal knowledge; 2) legal assessments; 3) legal guidelines.

Law affects the legal consciousness by the fact that it is the most important source of its formation, transformation and development. The content, direction of this influence are not clear and depends on the quality of legislation, its compliance with real needs, and the level of work of the state apparatus.

Along with legal awareness, the legal culture has a significant influence on the development of administrative and legal foundations. We will analyze the concept of legal culture within its influence on the development of information relations in order to formulate its own definition in accordance with the objectives of the diploma research. As you know, culture is a common way of human existence, its activities and the objective result of this activity. The products of culture are the notion of good and evil, customs, tools, means of communication, etc. Culture a phenomenon of socio-normative, and its norms - historically primary, the basis of all other normative systems: religion, morality, aesthetics, law. Right, as morality and religion, is an institution of culture, determined by its content.

Close interaction and interrelationship manifest between legal and moral culture. The legal culture consists of a series of interrelated elements.

1. The level of legal consciousness and legal activity of citizens is expressed in the degree of assimilation of rights by citizens, officials, the focus on observance of prohibitions, the use of rights, performance of duties.

2. Status of legal practice: a) the level of law-making activities and the state of law; b) the level of judicial, law enforcement and state of law practice. 
3. Regime of law and order - the state of actual ordering of social relations, settled by means of legal means, the content of which is a set of lawful actions of legal actors.

Particular attention in the development of the information society should be paid to the advance development of fundamental and applied research and science-intensive technologies, the development of the domestic programming industry, infrastructure of production of information and communication technologies. The need for a skilled approach and a rapid response to dynamic changes in the conditions of social life determines the separation of information relations, which are regulated by administrative law and determines the appropriate public administration, which requires a reassessment of the complex of tasks that need to be addressed.

The Cabinet of Ministers of Ukraine defined the plan of measures for the formation of the information and analytical system of state authorities in full time, although some concrete steps were taken: the draft Concept for the formation and functioning of the information and analytical system of state authorities and local self-government bodies was elaborated; A technical task has been prepared for system creation; The draft of the first stage of such a system for the President of Ukraine, the Secretariat of the Cabinet of Ministers of Ukraine, the Office of the National Security and Defense Council, a number of ministries and state committees has been developed.

Even before the expiration of the time allocated for the implementation of the measures, the specified resolution (and in general the idea of an integrated information and analytical system) was abolished.

The "E-Ukraine" project, which was supposed to be implemented in the test mode at the end of 2010, and from the first quarter of 2011 - to industrial exploitation, is limited to ensuring protection of the interaction of state authorities with each other. The developers of the tasks of the National Informatization Program for 2010-2012 state that the document "focuses on the creation and implementation of integrated projects that will form the modern information infrastructure of the state. Necessary constituent components of the state integrated information and analytical system are: subsystem of inter-departmental electronic document circulation; subsystem of monitoring of the socio-ecological and economic situation; automated government subsystem; a subsystem containing the geoinformation base of the territory; a subsystem that provides electronic interaction between citizens and organizations with 
power structures, in particular, the automation of the provision of public services and the receipt of reporting.

The contradictory situation is that "today, in the context of the development of the volume of social functionality that the system performs, and new forms of development in which the system level of the software becomes relatively autonomous from the hardware level, the systems cease to be closed, separated from the social context. Sophisticated systems that only exchange e-mails with the outside world are no longer needed by anyone." 9

Creation of the automated system "Single window of submission of electronic reporting" resulted in the emergence of new information legal relations in the government, in particular, the mechanisms of electronic interaction between the controlling bodies of state power and reporting entities are regulated through the introduction of unified standards for the process of submission, processing, use and storage of reporting, proper regulatory, methodological, organizational and technological support for the interaction of the participants in the process of submission of the electro Noah statements.

For the development of information legal relations in the state administration, the creation of the Unified State Portal for administrative services played a significant role. The only portal became the official source of information on the provision of administrative services in Ukraine.

The only state portal of administrative services provides: access to information about administrative services provided to the subjects of treatment; access to information about centers and entities providing administrative services; search by keywords in the fields of description of the administrative service; classification and search of services for life situations and categories; the submission by electronic means of applications and other documents to be submitted by subjects to be completed and submitted for reception of an administrative service; submission of on-line applications for administrative services; introduction of a fixed fee for the provision of administrative services using electronic payment systems; tracking the stages of passing documents on the provision of administrative services; tracking visit statistics; protection of data from unauthorized access, destruction,

${ }^{9}$ Цимбалюк В. С. Інформаційне право (основи теорії і практики) : монографія. Київ : Освіта України, 2010. 388 с. С. 248-249. 
modification and blocking by means of implementation of organizational and technical measures, means and methods of technical protection of information; delimitation and control of access to the information on the portal, in accordance with the powers of users; representation of the structure of information resources and Ukrainian-language interfaces, understandable for users ${ }^{10}$.

As a conclusion, it can be noted that today state regulation in the field of information and communication technologies is one of the priority directions of the state's activity, which, in its turn, causes the emergence and dynamic development of information relations in the field of public administration. Evolution of these relations allows to distinguish the following trends: information presence and provision of services to organizations and the population using information and communication technologies, including through websites; introduction of information and communication technologies in all spheres of state administration, including electronic interaction between authorities, with organizations, citizens - "e-government" and "electronic democracy"; the transformation of public administration, where information and communication technologies are one of the main catalysts of the transformations of the public sector.

Conclusions and further researches directions. Paramount role in determining the nature of information relations in administrative law belongs to their actors. Such parties are the administrative law actors, that is, the media provided by the administrative-legal norms of rights and obligations that can implement these rights, and the duties assigned to perform. Thus, information relations in administrative law are always of a public-power nature.

Further evolution of information technologies requires finding rational strategies for their development and management of this process, in particular, the stability of the work of state administration will not only intensify the use and dissemination of information technology in their activities, but also achieve the balance of information provision in the new environment. The organization of fundamental and applied scientific research in the field of information activity, in particular, the development and implementation of the latest information and communication

${ }^{10}$ Пилипчук В. Г., Брижко В. М. Проблеми становлення і розвитку інформаційного законодавства в контексті євроінтеграції України. Інформаџія і право. 2011. № 1(1). С. 11-19. С. 12. 
technologies, promotion of the development of information technologies and their implementation, providing access to world information scientific sources, will provide the basis for further genesis of information relations in the administrative law.

Priorities of the legislative provision of the development of information relations in the administrative law should be oriented towards the development of programs for the development of the information sphere. Priority is given to ensuring wide access to the network information technology of the private sector, which requires certain political, legal, economic and organizational conditions: the development of the scientific and technical base of information technology, the training of skilled personnel in this field, information security, the elimination of the lack of information and information services (especially in the legal field), etc.

\section{SUMMARY}

The article deals with theoretical comprehension and complex solution of the problems of administrative and legal regulation of information relations in Ukraine. The conceptual apparatus of this problem and the approach to formation of updated information relations, which are regulated by means of administrative law of Ukraine, have been improved. The formation and development of administrative-legal regulation of information relations has been considered, their essence and features have been determined. It has been noted that administrative law regulates public-legal informational relations, which possess all the properties of administrative legal relations and have their own distinctive features. The subject structure of information relations in administrative law, the characteristic of the object of information relations in the public area, the content of information relations in the administrative law has been disclosed. The foreign experience of legal regulation of information relations has been generalized, the possibilities of its use in Ukraine have been determined, in particular the application of the monitoring system and information and analytical support. Proposals and recommendations for improvement of the legislation in this area have been formulated.

\section{REFERENCES}

1. Адміністративне право України: акад. курс : підручник. У 2 т. Т. 1. Загальна частина / за ред. В. Б. Авер'янова. Київ : Юрид. думка, 2004. 584 c. 
2. Баранов О. А., Жиляєв І. Б., Семенченко А. І. Українське інформаційне право на початку XXI століття. Інформатизація та відкритість влади як засоби демократизації суспільства. Київ : Либідь, 2003. С. 88-100.

3. Бевзенко В. М. Сутність та поняття адміністративно-правового регулювання. Вісник господарського судочинства. 2006. № 3. С. 162-167.

4. Горбулін В. П., Биченок М. М. Проблеми захисту інформаційного простору України : монографія. Київ : Інтертехнологія, 2009. $136 \mathrm{c}$.

5. Доповідь про стан інформатизації та розвиток інформаційного суспільства в Україні за 2013 рік. URL.: http://www.dknii.gov.ua/sites/ default/files/stan_informatyzacii_20132.pdf.

6. Залізняк В. Удосконалення інформаційного законодавства України : методологічні засади. Інформаціийне право. 2010. № 2. C. $59-60$.

7. Концепція створення та функціонування інформаційної системи електронної взаємодії державних електронних інформаційних ресурсів. Офіиійний вісник України. 2012. № 67. Ст. 2753.

8. Панова I. В. До проблем правотворення в інформаційному праві. Правова інформатика. 2015. № 1 (45). С. 35-40.

9. Пилипчук В. Г., Брижко В. М. Проблеми становлення i розвитку інформаційного законодавства в контексті євроінтеграції України. Інформація і право. 2011. № 1(1). С. 11-19.

10. Чубарук Т. В. Конституційні засади правового регулювання інформаційної сфери. Правова інформатика. 2010. № 3(27). C. 61-65.

11. Цимбалюк В. С. Інформаційне право (основи теорії i практики) : монографія. Київ : Освіта України, 2010. 388 с.

\section{Information about the author: Korniyenko M. V. Doctor of Law, Professor, of the Dnipro Humanitarian University} Professor of the General Legal Disciplines Department 35, Yermolovoi str., Dnipro, 49033, Ukraine 